TITLE:

\title{
NOTES ON FIVE SPECIES OF THE AMPHIPOD GENUS AMPELISCA FROM THE STOMACH CONTENTS OF THE TRIGLID FISHES
}

AUTHOR(S):

Nagata, Kizo

CITATION:

Nagata, Kizo. NOTES ON FIVE SPECIES OF THE AMPHIPOD GENUS AMPELISCA FROM THE STOMACH CONTENTS OF THE TRIGLID FISHES. PUBLICATIONS OF THE SETO MARINE BIOLOGICAL LABORATORY 1959, 7(2): 263-278

ISSUE DATE:

1959-05-30

URL:

http://hdl.handle.net/2433/174606

RIGHT: 


\title{
NOTES ON FIVE SPECIES OF THE AMPHIPOD GENUS AMPELISCA FROM THE STOMACH CONTENTS OF THE TRIGLID FISHES
}

\author{
KIzO NAGATA \\ Naikai Regional Fisheries Research Laboratory
}

With 11 Text-figures

It is well known that the amphipods are often found abundantly in the stomach contents of various benthos feeders as prey-animals. The amphipod genus Ampelisca is one of the most important inhabitants on every marine soft bottom deeper than low tide marks and is also commonly found in the stomach contents of fishes caught in the Seto Inland-sea, Japan.

I had now an opportunity to observe the stomach contents of benthos-feeding fishes taken by the experimental two-boat trawlers which cruised over eleven "Nada" areas around the coast of Shikoku Island.

The materials here dealt with have been obtained only from the fishes belonging to the family Triglidae in the catches of the five times cruises carried on from September 1957 to August 1958. The amphipod genus Ampelisca was found in the following six species of this family: 1) Pachytrigla alata (Houttuyn), 2) Lepidotrigla japonica (BleEKer), 3) L. gïntheri Hilgendorf, 4) L. abyssalis JoRdAn et STARKs, 5) L. kishinouyi SNyder and 6) L. microptera Günther.

The stations for the experimental fishing are all on the continental shelf : 20-60 metres depth in inner areas, 60-130 metres depth in outer areas along the Pacific coast of Shikoku.

Marine Gammaridean amphipods from the coasts of Japan and its adjacent waters have been reported by Stebbing (1888), STEPHEnSEN (1932, 1944), Buiycheva (1936), IWASA (1939, 1957), DAHL (1945), etc., but there are only a few records on the genus Ampelisca.

DAHL described in 1945 three species (A. brevicornis, A. bocki n. sp., A. misakiensis n. sp.) from the Pacific coast of Japan, mainly Sagami Bay. Bulcheva reported in 1936 on two new species (A. furcigera n. sp., A. birulai n. sp.) from the Japan Sea. And then IwaSA described in 1957 two species (A. diadema, A. zamboangae) briefly with some figures from the seas of Kyûshû, Ryûkyû Islands and Formosa.

The present report comprises five species of which three seem to be new ones.

Publ. Seto Mar. Biol. Lab., VII (2), 1959. (Article 13) 


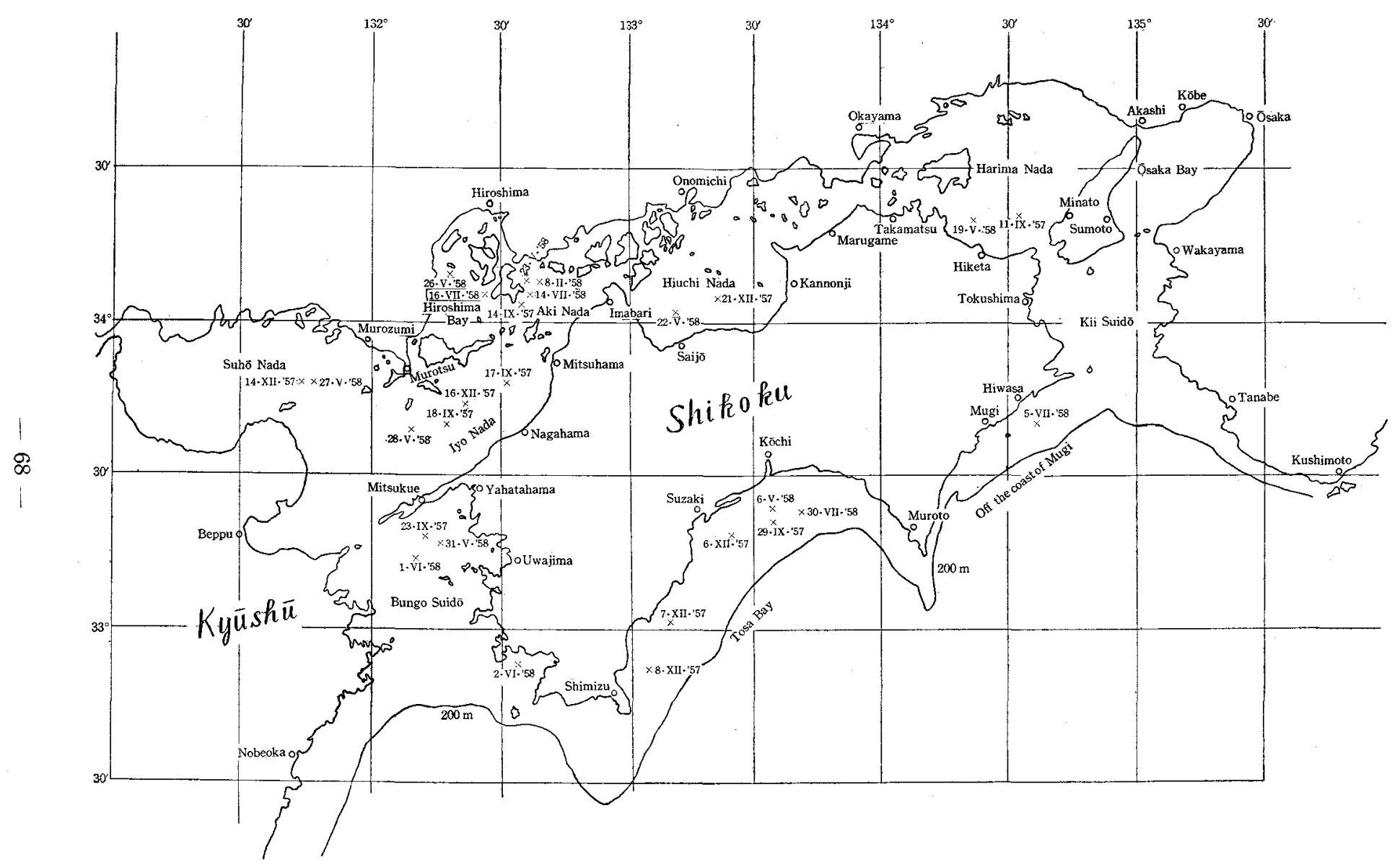

Fig. 1. Chart showing the location of stations $(x)$, where triglid fishes containing the amphipod genus Ampelisca in the stomach contents were captured by the experimental two-boat trawlers from September 1957 to August 1958. 
I wish to acknowledge the opportunity and aid given by Dr. T. HANAOKA, chief of the Naikai Regional Fisheries Research Laboratory for this study and preparing this paper and for offering the available materials collected by the staff of the Laboratory. I am deeply indebted to Dr. H. UTinom of the Seto Marine Biological Laboratory, Kyoto University, for his constant guidance and many valuable advices throughout the course of this work. My thanks are also due to Dr. S. MiYake of Kyushu University for his advices and offering the reprints useful to my work.

\section{Ampelisca brevicornis (A. CostA)}

(Fig. 2)

SARS, 1891, p. 169, pl. 59, fig. 1 (laevigata).

Stebbing, 1906, p. 100.

Chevreux et FAGE, 1925, p. 74, fig. 69.

BARNARD, 1932, p. 84.

Pirlo't, 1936, p. 277.

BARNARD, 1937, p. 148.

DAHL, 1945, p. 9 , fig. 8 (cf. brevicornis).

Occurrence:

\begin{tabular}{|c|c|c|c|c|c|c|c|}
\hline \multicolumn{4}{|c|}{ 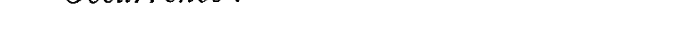 } & \multicolumn{2}{|c|}{ From stomach of } & \multirow[b]{2}{*}{$\begin{array}{l}\text { L. } \\
\text { guntheri }\end{array}$} & \multirow[b]{2}{*}{$\begin{array}{l}L . \\
\text { abyssalis }\end{array}$} \\
\hline 'Nada'-area & Date & $\begin{array}{l}\text { L. } \\
\text { microptera }\end{array}$ & $\begin{array}{l}\text { L. } \\
\text { kishinouyi }\end{array}$ & $\begin{array}{l}P . \\
\text { alata }\end{array}$ & $\begin{array}{l}\text { japonica } \\
\end{array}$ & & \\
\hline \multirow[t]{3}{*}{ Tosa Bay } & $29-9-1957$ & . & . & - & 14 & . & . \\
\hline & $6,7,8-12-57$ & . & . & 3 & 18 & . & . \\
\hline & $30-7-’ 58$ & . & . & . & 9 & . & . \\
\hline \multirow[t]{2}{*}{ Bungo Suidô } & $23-9-' 57$ & 1 & . & . & . & . & . \\
\hline & $1,2-5-' 58$ & 2 & 1 & - & 1 & 1 & . \\
\hline \multirow[t]{2}{*}{ Iyo Nada } & $17,18-9-57$ & 3 & - & - & - & - & - \\
\hline & $28-5-58$ & 4 & 1 & . & - & - & . \\
\hline \multirow[t]{3}{*}{ Suhô Nada } & $14-12-' 35$ & 2 & - & $:$ & - & - & - \\
\hline & $27-5-' 58$ & 4 & 2 & - & - & - & . \\
\hline & $17-7-^{\prime} 58$ & 3 & . & . & . & . & . \\
\hline \multirow[t]{2}{*}{ Hiroshima Bay } & $26-5-' 58$ & 9 & . & . & . & . & . \\
\hline & $14,16-7-58$ & 2 & . & . & . & . & 2 \\
\hline Aki Nada & $22,23-5-^{-} 58$ & 6 & . & . & . & . & . \\
\hline Hiuchi Nada & $21-12-' 57$ & 1 & . & - & - & - & - \\
\hline Harima Nada & $19-5-’ 58$ & 3 & . & . & . & . & . \\
\hline
\end{tabular}

Remarks: Length of specimens up to $12 \mathrm{~mm}$. Lateral lobe of head slowly rounded. Anterodistal corner of article 4 of pereiopod 3 much produced nearly to distal end of article 5; article 7 of pereiopod 3 about 1.5 times as long as 5 and 6 combined. Article 3 of pereiopod 7 subequal in length to article 4 of which back lobe drawn out into a long, broad and rounded corner. Postero-inferior margin of pleon segment 3 somewhat less sinuated than in SARs' and Crievreux' figures. Apices of telson and rami of uropod 3 less pointed.

This is known as cosmopolitan species, as reported from N. Atlantic, Mediterranean, 
the coast of Africa, Indian Ocean, Tropical Pacific and also the coast of Japan, where this species was described by DAHL in 1945 from Kobe Bay.

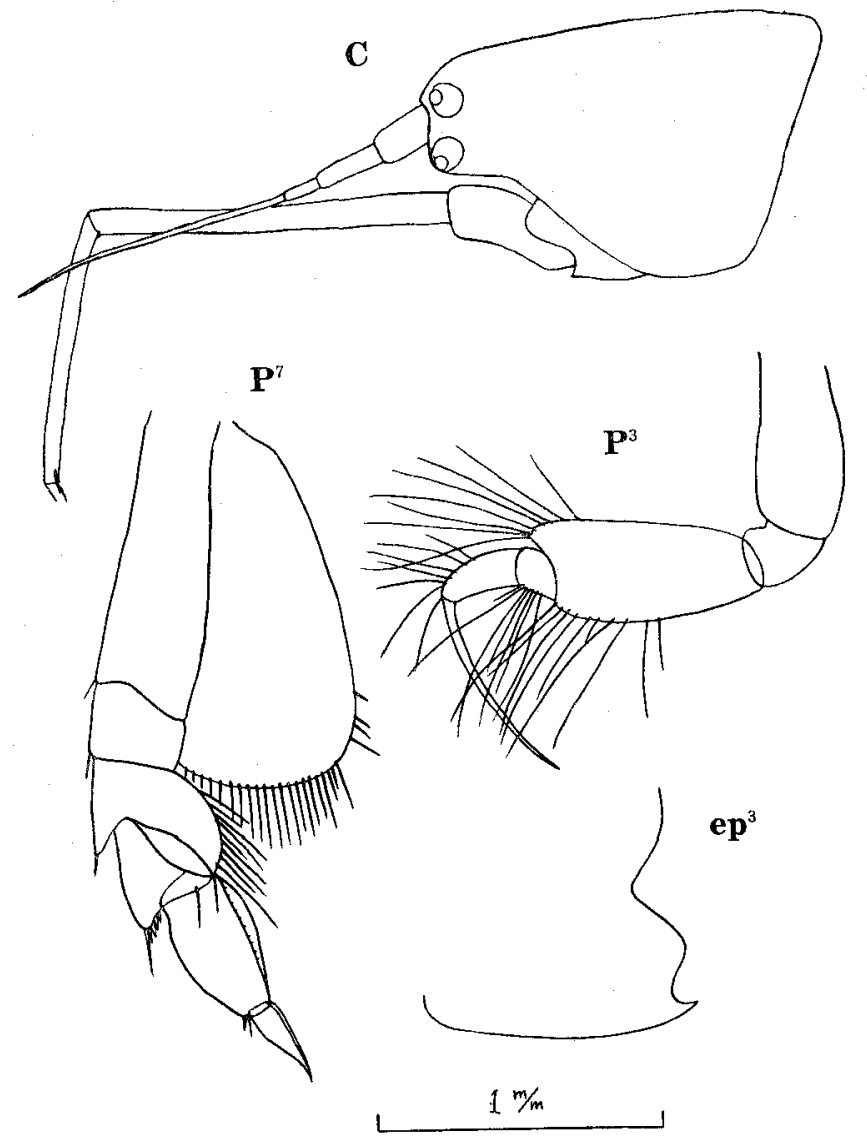

Fig. 2. Ampelisca brevicornis (A. CostA), ovig. female.

$\mathrm{C}$, head; d.c., dorsal carina of pleon segments 4-6; $\mathrm{ep}^{3}$, 3rd epimeral plate (posterior edge of pleon segment 3 ); $\mathrm{P}^{1}-\mathrm{P}^{2}, 1$ st-2nd pereiopod (gnathopod); $\mathrm{P}^{3}-\mathrm{P}^{7}$, 3rd-7th pereiopod; t, telson; $\mathrm{up}^{3}$, 3rd uropod.

\section{Ampelisca miharaensis n. sp.}

(Figs. 3-5)

Occurrence :

\begin{tabular}{|c|c|c|c|c|c|c|}
\hline \multirow[b]{2}{*}{ 'Nada'-area } & \multirow[b]{2}{*}{ Date } & \multicolumn{5}{|c|}{ From stomach of } \\
\hline & & $\begin{array}{l}L . \\
\text { microptera }\end{array}$ & $\begin{array}{l}\text { L. } \\
\text { kishinouyi }\end{array}$ & $\begin{array}{l}P . \\
\text { alata }\end{array}$ & $\begin{array}{l}L . \\
\text { japonica }\end{array}$ & $\begin{array}{l}L . \\
a b y s s a l i s\end{array}$ \\
\hline \multirow[t]{3}{*}{ Tosa Bay } & 29-9-1957 & 3 & . & - & 29 & - \\
\hline & $6,7-12-' 57$ & - & - & 3 & 5 & . \\
\hline & $30-7-' 58$ & - & - & - & 1 & $\cdot$ \\
\hline \multirow[t]{2}{*}{ Bungo Suidô } & $2-5-' 58$ & • & 1. & - & - & 1 \\
\hline & $22-7-58$ & - & 1 & - & . & - \\
\hline
\end{tabular}


Desciption of ovigerous female: Length $7 \mathrm{~mm}$. Anterior edge of head strongly incised; lateral lobe conspicuously produced; lower front margin obliquely straight; upper pair of eyes behind antenna 1 ; lower pair of eyes below lateral angle on the lower front margin.

Antenna 1 a little shorter than antenna 2 (both antennae much setose on confrontal

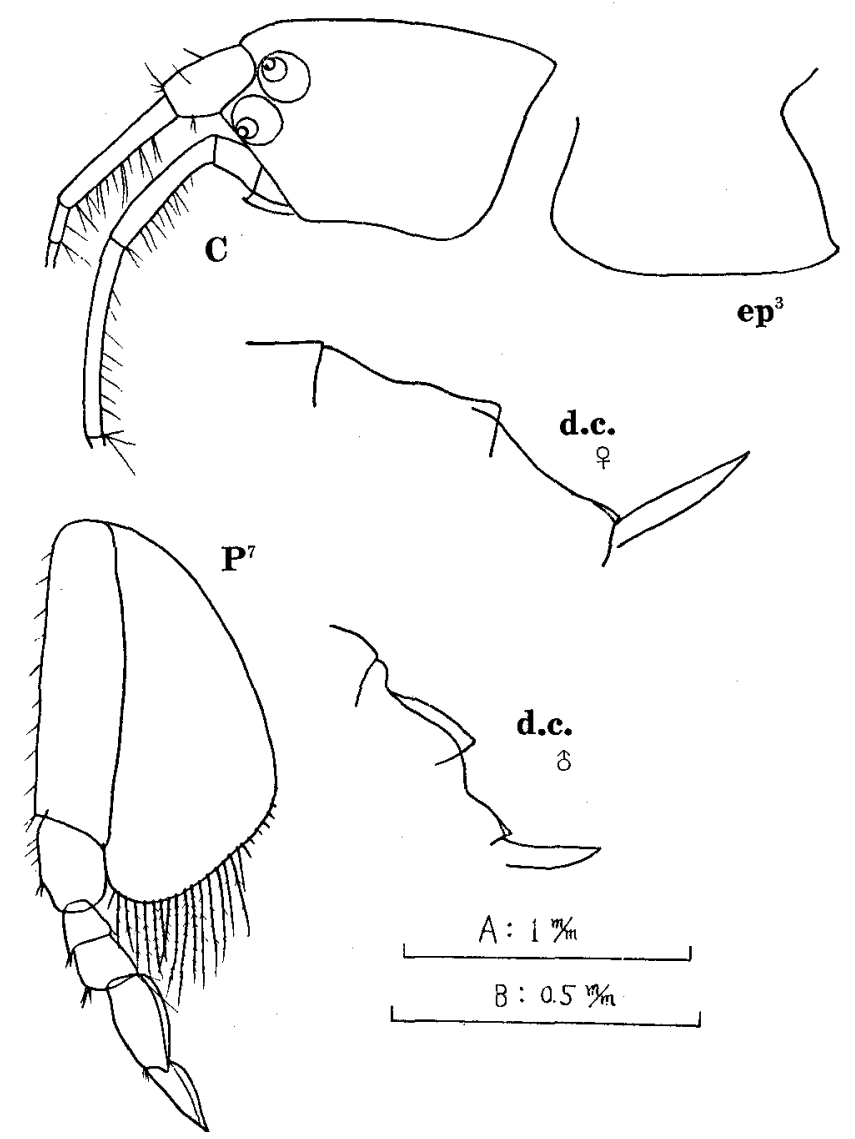

Fig. 3. Ampelisca miharaensis n. sp., ovig. female, $7 \mathrm{~mm}$ and male $4.5 \mathrm{~mm}$. Legend as before.

A scale: C, d.c., $\mathrm{ep}^{3}, \mathrm{up}^{3}, \mathrm{P}^{3}, \mathrm{P}^{4}$, and $\mathrm{P}^{7}$.

$\mathrm{B}$ scale: $\mathrm{P}^{1}, \mathrm{P}^{2}$, and $\mathrm{t}$.

margin); article 2 of peduncle about 1.5 times as long as 1 which is tumid; article 3 of peduncle about one-fourth as long as 2 ; flagellum 20-jointed.

Antenna 2 more than one half times as long as body; article 5 of peduncle longer than 4 ; flagellum 22-jointed.

Pereiopod 1: article 6 about two-thirds as long as 5 ; posterior edge of article 6 slightly convex; article 7 about one half as long as 6 . 
Pereiopod 2: article 6 about one half as long as 5 ; article 7 one half as long as 6 .

Pereiopod 3: anterodistal angle of article 4 almost not produced; article 7 slightly longer than 5 and 6 combined.

Pereiopod 4 more setose than pereiopod 3 ; anterodistal corner slightly produced; article 7 a little longer than 5 and 6 together.

Pereiopod 5 and 6 without special characteristics.
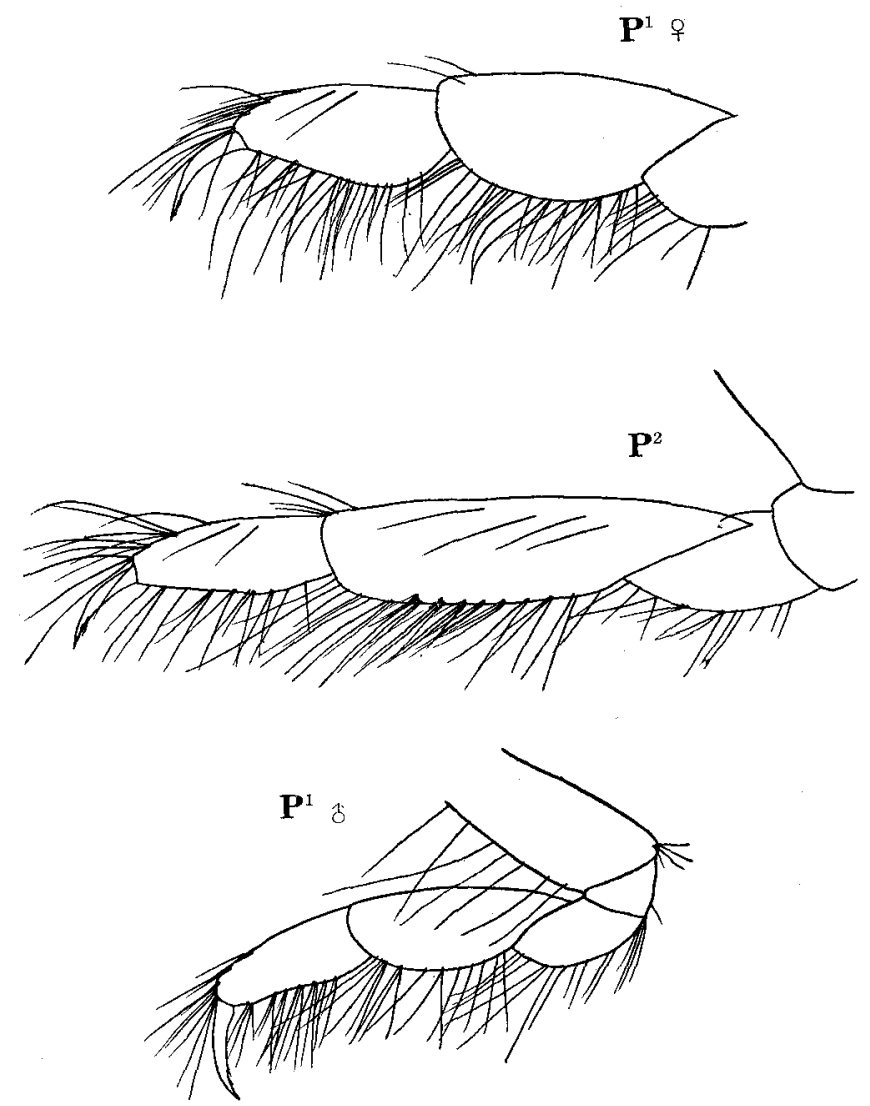

Fig. 4. Ampelisca miharaensis $\mathrm{n}$. sp., ovig. female, $7 \mathrm{~mm}$ and male, $4.5 \mathrm{~mm}$. Legend as before.

Pereiopod 7: lower hind edge of posterior lobe of article 2 obliquely rounded somewhat straight; its lobe nearly reaching as far as distal end of article 3 ; article 4 much shorter than 3 ; article 5 slightly longer than 4 ; article 6 twice as long as 5 ; article 7 slightly shorter than 6 .

Uropod 1 reaching slightly beyond end of uropod 2; rami subequal in length and also equal to peduncle; outer edge of inner ramus and inner edge of peduncle spinulate respectively. 
Uropod 2: rami shorter than peduncle; outer edge of each ramus and each side of peduncle spinulate respectively.

Uropod 3: outer ramus slender, subequal length to the inner ramus which is moderately broad; inner edge of inner ramus with several long setae; both side of outer ramus with many small spines.
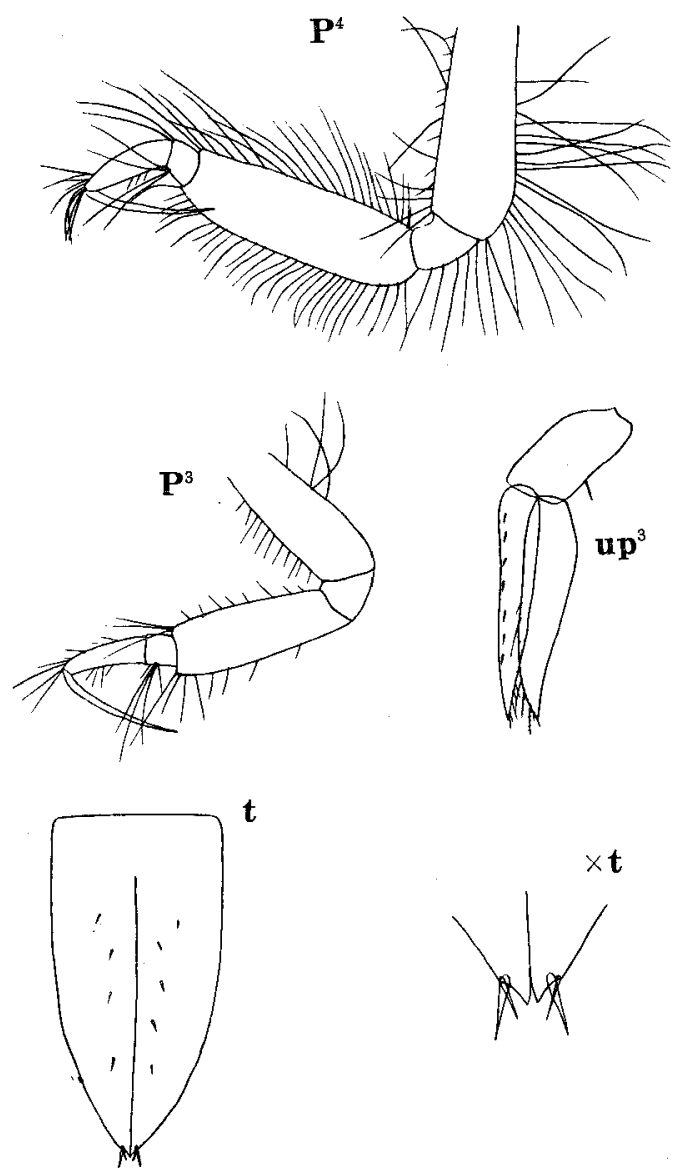

Fig. 5. Ampe!isca miharaensis n. sp., ovig. female, $7 \mathrm{~mm}$ and male, $4.5 \mathrm{~mm}$. Legend as before.

Telson twice as long as broad, tapering to the apex which is pointed and slightly notched; its notch with one spine and one spinule; upper surface of each lobe with several spinules; cleft to about five-sixths of all length.

Pleon segment 3: posterior edge slightly convex; lower hind corner with a small blunt tooth.

Pleon segment 4: dorsal posterior surface not so strongly developed.

Pleon segment 6 : lateral ridges with a weak process. 
Male $4.5 \mathrm{~mm}$ in length. Differing from the female by the setal tufts on the peduncle of antennae, by the length of antenna 2 about equal to body, by the posterior dorsal surface of pleon segment 4 raised into a slightly saddle-shaped process and by the lateral ridges of pleon segment 6 more developed. Particularly, the most characteristic point is the shape of article 6 of pereiopod 1 which is slender and oblong with a shallow convex along posterodistal margin.

Type locality: Mihara Bay, Hiroshima prefecture. Collected by Ekman's grabsampler.

Remarks: Length of specimens up to $9 \mathrm{~mm}$. The species is similar to $A$. serraticaudata CHEvREux in the relative proportion of length between 1 st and 2 nd antennae, the shape of head and posterior lobe of article 2 of pereiopod 7, and hind lower corner of pleon segment 3 , but differs in rather shorter dactylus of pereiopod 3 and 4 , the length of dactylus of pereiopod 7, the slender form of uropod 3 and the shape of the apex of telson. And also this resembles $A$. aequicornis Bruzel., but differs in the relative proportion of length of peduncle of antenna 1 , the structure of pereiopod 4, the shape of back lobe of article 2 of pereiopod 7 and the length of article 7 of this appendage. From A. milleri J. BARNARD it differs in the lack of prominent posterodistal corner of article 5, longer dactylus of pereiopod 7 and the slender uropod 3.

This species is named from Mihara Bay, where a large number of this species were collected in 1955 .

Ampelisca naikaiensis $\mathrm{n}$. $\mathrm{sp}$.

(Figs. 6-8)

Occurrence :

\begin{tabular}{|c|c|c|c|c|}
\hline \multirow[b]{2}{*}{ 'Nada'-area } & \multicolumn{4}{|c|}{ From stomach of } \\
\hline & Date & $\begin{array}{l}L . \\
\text { nicroptera }\end{array}$ & $\begin{array}{l}P . \\
\text { alata }\end{array}$ & $\begin{array}{l}\text { L. } \\
\text { japonica }\end{array}$ \\
\hline \multirow[t]{3}{*}{ Tosa Bay } & 29-9-1957 & . & 4 & 7 \\
\hline & $6-5-' 58$ & 1 & . & . \\
\hline & $30-7-58$ & . & . & 20 \\
\hline Bungo Suidô & $31-5,2-6-58$ & $8 \quad 4$ & . & 1 \\
\hline \multirow[t]{3}{*}{ Iyo Nada } & $17-9-57$ & 8 & . & . \\
\hline & $16-12-' 57$ & 1 & . & . \\
\hline & $28-5-' 58$ & 1 & . & . \\
\hline Suhô Nada & $14-12-' 57$ & 10 & - & - \\
\hline \multirow[t]{3}{*}{ Aki Nada } & $14-9-57$ & 5 & . & . \\
\hline & $8-2-' 58$ & 2 & . & . \\
\hline & $22,23-5-58$ & 7 & . & . \\
\hline Hiuchi Nada & $22-5-' 58$ & 4 & . & . \\
\hline Harima Nada & 11-9-'57 & 2 & - & . \\
\hline $\begin{array}{l}\text { Off the coast of Mugi, } \\
\text { Tokushima Prefecture }\end{array}$ & $5-7-' 58$ & 1 & - & . \\
\hline
\end{tabular}


Description of evigerous female: Length $75 \mathrm{~mm}$. Anterior edge of head slightly incised; lower front margin obliquely, rather straight; upper pair of corneal lenses behind upper edge of antenna 1, lower pair below lateral angle of head.

Antenna 1 reaching beyond end of peduncle of antenna 2; article 2 of peduncle less than twice as long as 1 ; article 3 shorter than 1 ; flagellum 7 -jointed.

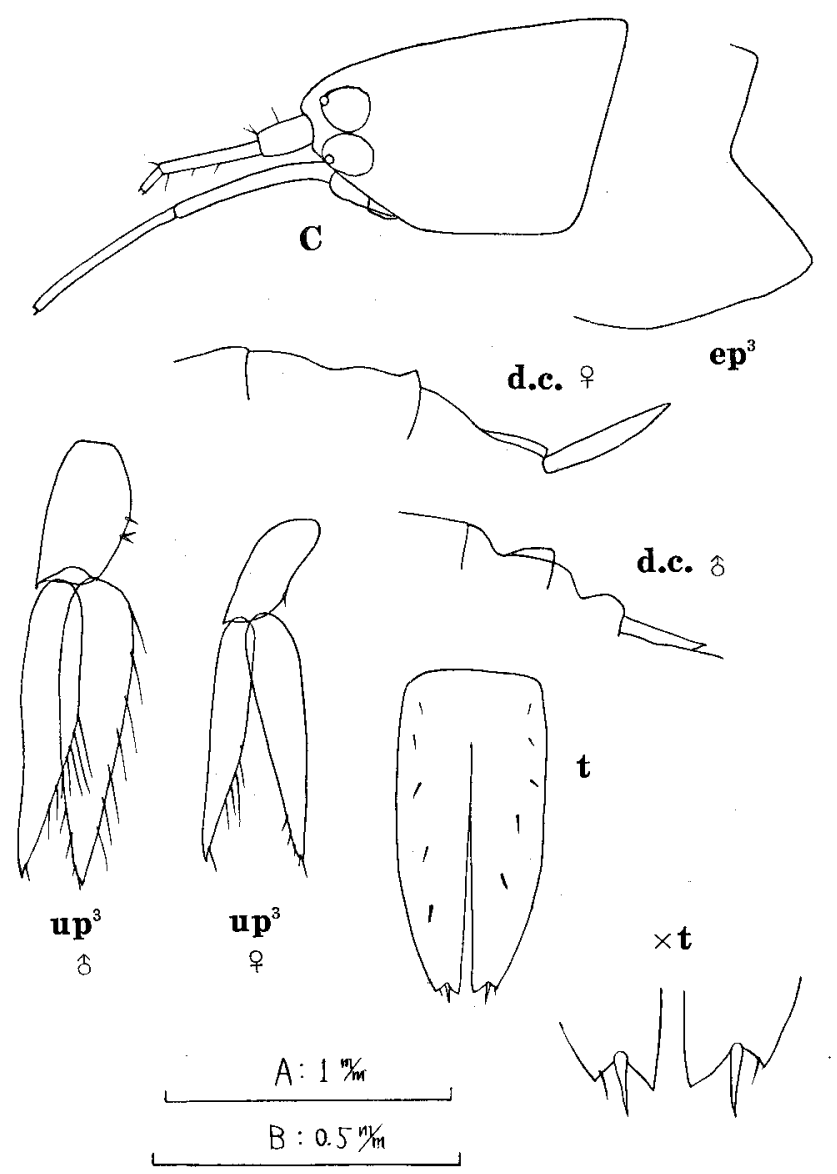

Fig. 6. Ampelisca naikaiensis n. sp. ovig. female, $7.5 \mathrm{~mm}$ and male, $4.5 \mathrm{~mm}$. Legend as before.

A scale: C, d.c., $\mathrm{P}^{3}, \mathrm{P}^{4}, \mathrm{P}^{7}$, up $\mathrm{up}^{3}-$ female.

B scale: $\mathrm{P}^{1}, \mathrm{P}^{2}, \mathrm{t}$, and $\mathrm{up}^{3}$-male.

Antenna 2 extending to only a half length of body; article 5 of peduncle slightly longer than 4 ; flagellum 12 -jointed. Both antennae slim and slender.

Pereiopod 1: article 6 oblong, about two-thirds as long as 5 ; posterior edge slightly concave with a long and strong setal spine; article 7 long, slender, about two-thirds as long as 6. 
Pereiopod 2 long and slender; article 5 about 2.5 times as long as 6 which nearly straight at posterior margin; article 7 slightly more than one half as long as article 5 .

Pereiopod 3: article 4 rather slender, anterodistal angle almost not produced; article 7 longer than 5 and 6 combined.

Pereiopod 4: article 4 broader than 5 and 6 and more setose than pereiopod 3; its anterodistal corner not produced; article 7 longer than 5 and 6 combined.

Pereiopod 5 and 6 with no special characteristics.

Pereiopod 7 : inferior hind margin of back lobe of article 2 rounded, extending
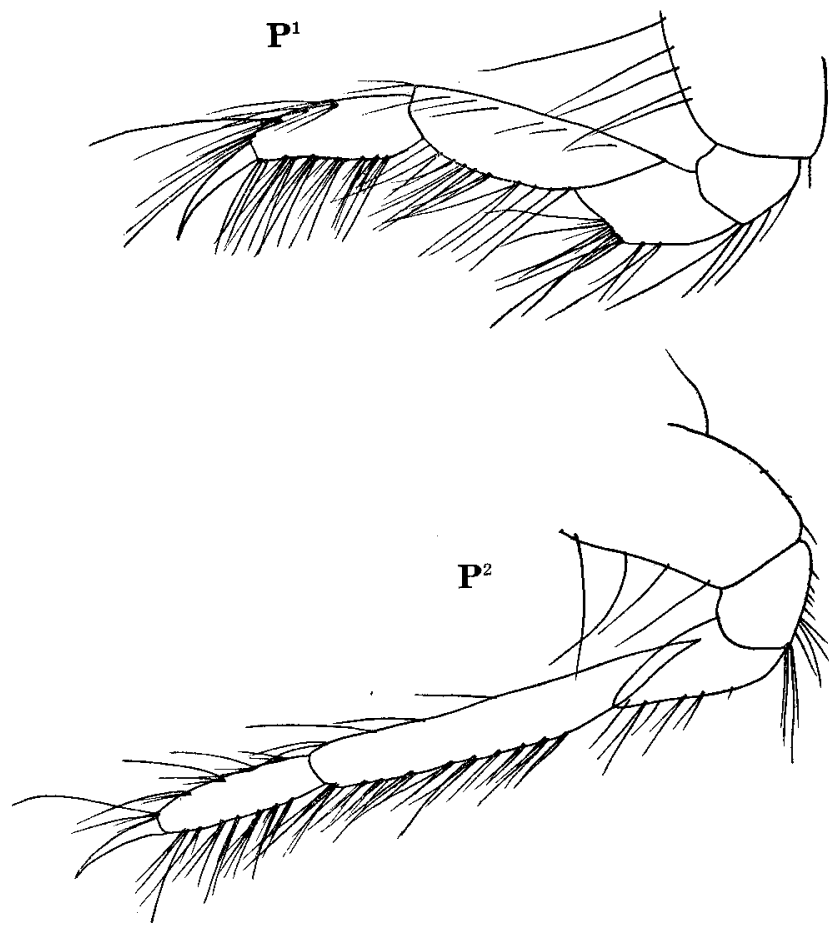

Fig. 7. Ampelisca naikaiensis n. sp., ovig. female, $7.5 \mathrm{~mm}$ and male, $4.5 \mathrm{~mm}$. Legend as before.

to distal end of article 3 which is much longer than 4 ; article 5 slightly longer than 4 ; article 6 longer than 7 .

Uropod 1 reaching slightly beyond end of uropod 2; outer ramus a little longer than inner; peduncle and rami almost equal in length; outer edge of inner ramus with some spines.

Uropod 2: rami and peduncle equal in length; inner ramus slightly longer than outer; outer edge of inner ramus with some spines.

Uropod 3: rami subequal in length and slightly setose; outer ramus slightly slender than inner. 
Telson more than twice as long as broad, apices strongly notched with one spine and one setule; dorsal surface of each lobe with five spinules; cleft to four-fifths of all length.

Pleon segment 3: posterior edge almost straight; lower hind corner rounded.

Pleon segment 4: posterior dorsal surface raised into a weakly saddle-shaped process.
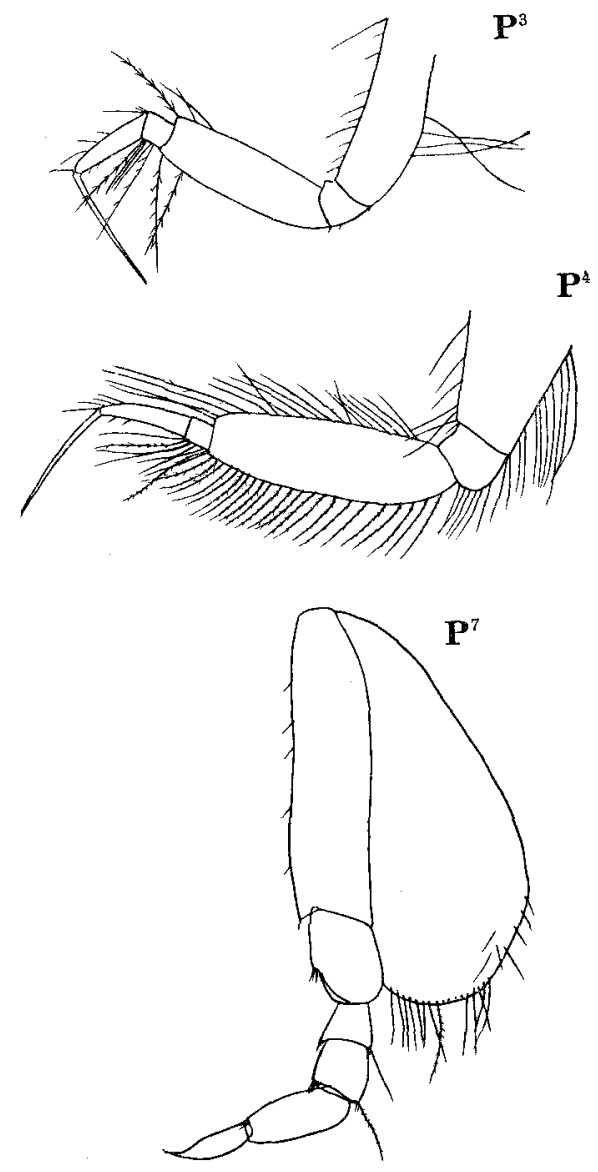

Fig. 8. Ampelisca naikaiensis n. sp., ovig. female, $7.5 \mathrm{~mm}$ and male, $4.5 \mathrm{~mm}$. Legend as before.

Pleon segment 6: lateral ridges low.

Male $4.5 \mathrm{~mm}$ in length. Antenna 2 reaching fully to the end of body; both antennae with the setal tufts on the peduncle; uropod 3 more setose than in female; pleon segment 4 and 6 raised higher than in female into the posterior dorsal surface.

Type locality: Mihara Bay. Collected by Ekman's grab type sampler.

Remarks: This species closely resembles A. spinimana CHEvreux in short 
antennae, the shape of back lobe of article 2 of pereiopod 7 and the shape of lower hind corner of pleon segment 3 , but differs in the structure of pereiopod 1 , the length of article 7 of pereiopod 3 and 4, the relative proportion of length of article 6 to 7 of pereiopod 7 , the strong notch at apices of telson, and in the shape of uropod 3.

These specimens have length of up to $8 \mathrm{~mm}$. Together with A. miharaensis, this species was also collected in Mihara Bay during the same survey, but there were a few in numbers.

\section{Ampelisca bocki DAHL}

DAHL, 1945, p. 2, figs. 1-3.

Occurrence:

\begin{tabular}{|c|c|c|c|c|}
\hline \multirow[b]{2}{*}{ 'Nada'-area } & \multirow[b]{2}{*}{ Date } & \multicolumn{3}{|c|}{ From stomach of } \\
\hline & & $\begin{array}{l}L \text { microptera } \\
\text { mo }\end{array}$ & $\begin{array}{l}L . \\
\text { japonica }\end{array}$ & $\begin{array}{l}\text { L. } \\
\text { abyssalis }\end{array}$ \\
\hline \multirow[t]{2}{*}{ Tosa Bay } & 29-9-1957 & . & 1 & ․ \\
\hline & $30-7-{ }^{\prime} 58$ & . & 2 & . \\
\hline ungo Suidô & $2-5-' 58$ & . & . & 1 \\
\hline dhô Nada & $27-5-58$ & 1 & . & . \\
\hline Aki Nad & $22-5-58$ & 1 & . & . \\
\hline
\end{tabular}

Remarks: These specimens show the entire agreement with DAHL's specimens which was described by DAHL in 1945 from Kobe Bay for the first time. Before this . investigations, this species was collected also from Mihara Bay by Ekman's grab. Specimens described above, have the length of up to $11 \mathrm{~mm}$.

\section{Ampelisca iyoensis n. sp.}

(Figs. 9-11)

Occurrence :

\begin{tabular}{llcc} 
& \multicolumn{3}{c}{ From stomach of } \\
‘Nada'-area & Date & L. & $\begin{array}{l}\text { L. } \\
\text { microptera }\end{array}$ \\
japonica
\end{tabular}

Description of male: Length $11 \mathrm{~mm}$. Anterior edge of head rounded without any incision; lower front margin parallel to upper margin; only a single lens on each side of head behind anterior edge.

Antenna 1 attached to lower front margin and reaching slightly beyond end of peduncle of antenna 2 ; second article more than two times as long as first; third article shorter than one half of first; setal tufts typically developed on peduncles of both antennae; flagellum 19 -jointed. 
Antenna 2 extending to pleon segment 3 ; article 4 much longer than 5 ; flagellum 54-jointed.

Pereiopod 1: article 6 with clearly separated palm and about two-thirds as long as 5 ; article 7 short.

Pereiopod 2: much more slender than pereiopod 1; article 5 about two times as long as 6 which has no apparent palm; article 7 short.

Pereiopod 3: anterodistal corner rather produced; article 7 longer than 5 and 6 combined.

Pereiopod 4: almost similar to 3 .

Pereiopod 5 and 6 with no special characteristics.

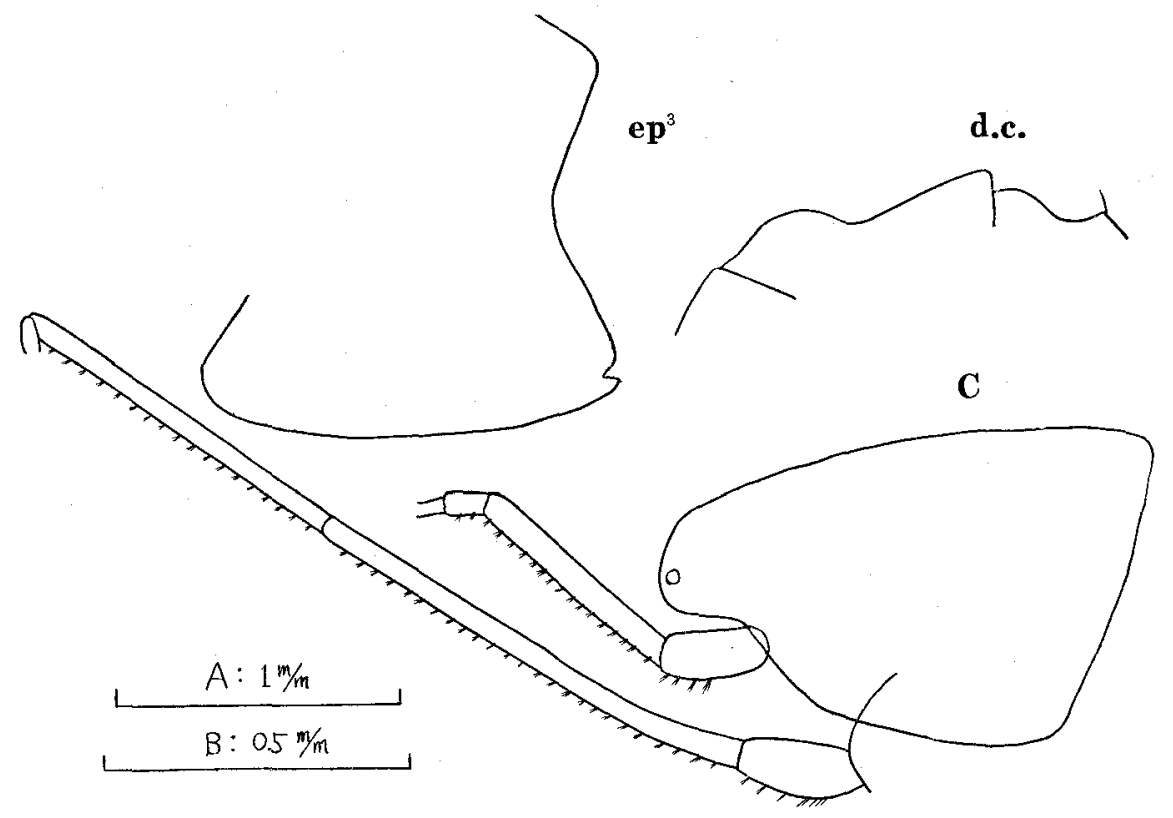

Fig. 9. Ampelisca iyoensis n. sp., male, $11 \mathrm{~mm}$. Legend as before.

Scale A: C, d.c., ep ${ }^{3}, \mathrm{P}^{1}, \mathrm{P}^{2}, \mathrm{P}^{3}, \mathrm{P}^{4}, \mathrm{up}^{3}$.

Scale B : $t$.

Pereiopod 7: lower hind margin of back lobe of article 2 rounded, extending to the middle of article 4 which is much shorter than 3 ; anterodistal corner of article 5 produced; article 6 longer than 4 and 5 combined; article 7 a little shorter than 6 .

Uropod 1 not reaching beyond the middle of rami of uropod 2 ; peduncle slightly longer than rami; outer ramus a little longer than inner; rami slender and smooth except proximal edge of inner ramus, here carrying three small spines.

Uropod 2: peduncle longer than rami; outer ramus shorter than inner; apices of outer and inner ramus with one long spine respectively.

Uropod 3: inner ramus slightly longer than outer; both rami much setose on both sides. 
Telson: rather robust, much constricted near base, tapering distally, carrying here a pair of strong notch with two setae and one setule respectively; cleft to one half of its length; upper surface of each lobe with 4-6 setae.

Pleon segment 3: posterior edge slightly convex; lower hind corner with a tooth.
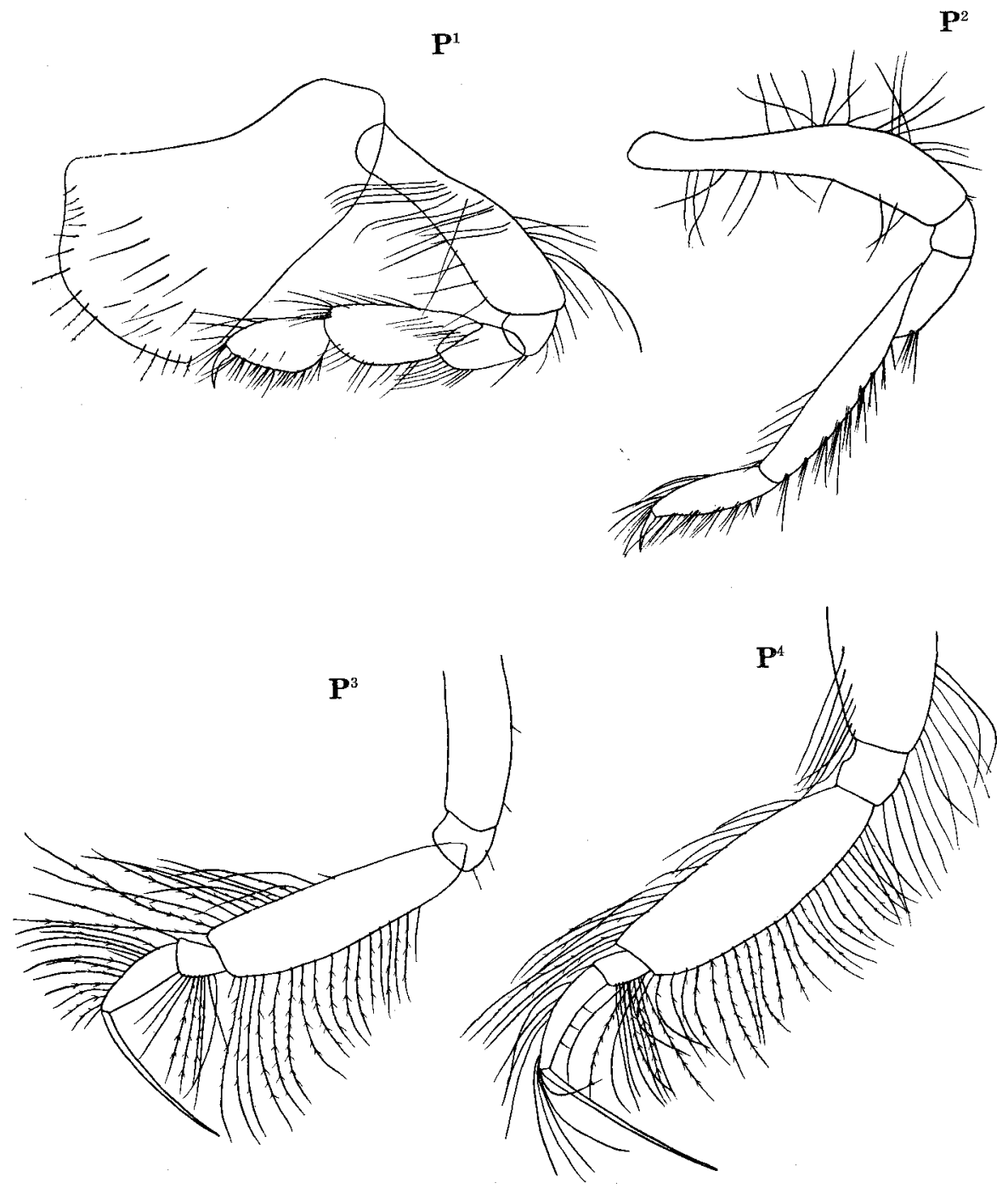

Fig. 10. Ampelisca iyoensis n. sp., male, $11 \mathrm{~mm}$. Legend as before.

Pleon segment 4: posterior dorsal surface raised into a subcrestate process.

Pleon segment 6: lateral crest not strongly developed.

Female: without any striking sexual differences, except no setal tufts on peduncles of antennae and relatively shortened ones. 
Type locality: Iyo Nada.

Remarks: All specimens are very large, up to $14 \mathrm{~mm}$ in length. This species somewhat resembles $A$. misakiensis DAHL in only one pair of lens and the attachmentpoint of 1st antenna, but differs in the structure of pereiopod 7, the shape of the head, lower hind margin of pleon segment 3, and telson. This species was encountered in the present investigation for the first time.

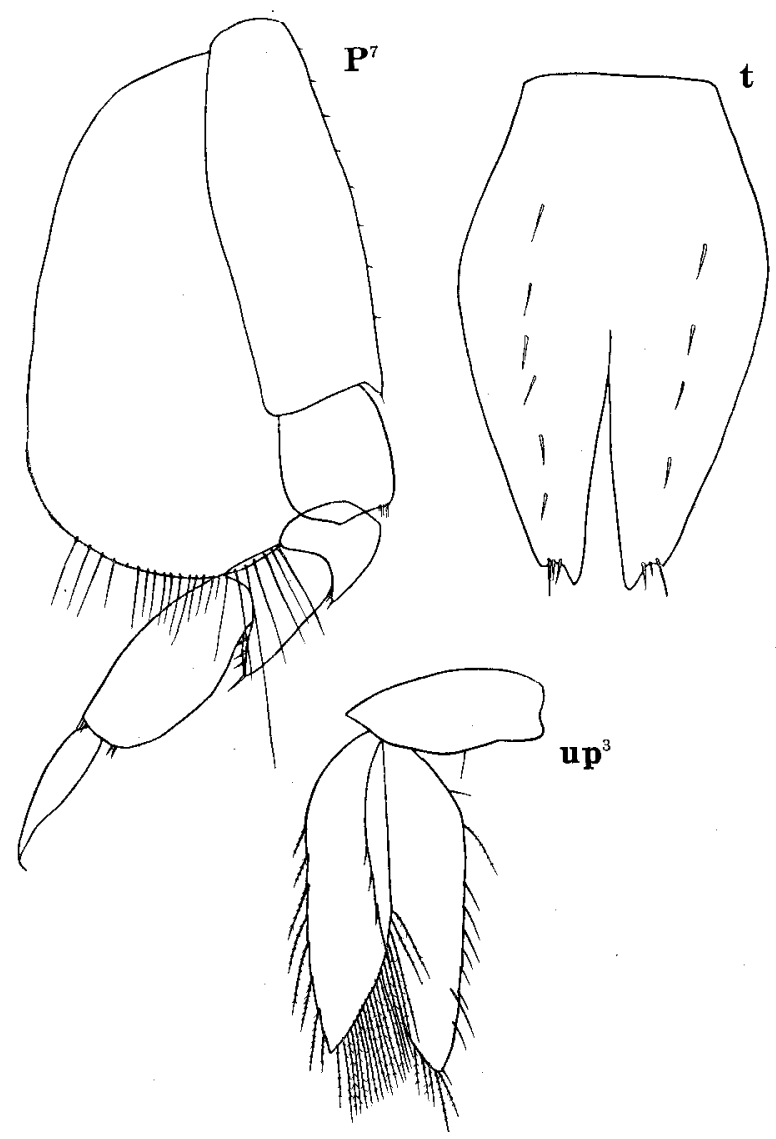

Fig. 11. Ampelisca iyoensis $\mathrm{n}$. sp., male, $11 \mathrm{~mm}$. Legend as before.

\section{REFERENCES}

BARNARD, J. L. 1954. Amphipoda of the family Ampeliscidae collected in the eastern Pacific Ocean by the Velero III and Velero IV. Allan Hancock Pacific Exped., 18 (1) : 1-61, pls. 1-38. 1958. Index to the families, genera, and species of the gammaridean Amphipoda. Allan Hancock Foundation Publications, Occasional paper, no. 19: 1-145.

BARnard, K. H. 1931. Amphipoda. Great Barrier Reef Exped., Sci. Rep., 4 (4): 111-135, 4 textfigs. 
- Barnard, K. H. 1932. Amphipoda. Discovery Reports, 5: 1-326, pl. 1, 174 text-figs.

__ 1937. Amphipoda. John Murray Exped., 4 (6): 131-201, 21 text-figs.

Bulycheva, A. 1936. New species of Amphipoda from the Japan Sea. Ann. Mag. Nat. Hist., ser. 10, 18: 242-256, 35 text-figs.

ChevreuX, E. et Fage, L. 1925. Amphipodes. Faune de France, 9: 1-488, 438 text-figs.

DAHL, E. 1945. Amphipoda of the family Ampeliscidae from Professor Sixten Bocks Exped. to Japan 1914. Arkiv för Zool., 36 (1) : 1-18, 10 text-figs.

Gules, G. M. 1890. Descriptions of seven aditional new Indian amphipods. Jour. Asiatic Soc. Bengal, $59: 63-74$, pl. 2.

IwASA, M. 1939. Japanese Talitridae. Jour. Fac. Sci. Hokkaido Imp. Univ., Zool. VI, 6 (4): 255-296, 27 text-figs., pls. 9-22, 1 table.

1957. Amphipoda. In : Illustrated encyclopedia of the fauna of Japan. Revised edition: 822-840, 51 figs. Hokuryukan Co., Ltd., Tokyo.

Pirlot, J. M. 1936. Les Amphipodes de l'Expedition du Siboga. III Les Amphipodes Littoreux. Monogr., 3e, 253-328, text-figs. 102-146.

Sars, G. O. 1895. An account of the Crustacea of Norway. Amphipoda. 1: 1-711, 240 pls., 8 suppl. pls.

Scheltenberg, A. 1931. Gammariden und Caprelliden Magellangebietes, Südgeorigen und der Westantarktis. Further Zool. Res. Swedish Antarctic Exped. 1901-03, 2 (6): 1-290, 1 pl., 136 text-figs.

1938. Littorale Amphipoden des Tropischen Pazifiks. Handl. Svenska Vetensk. Akad., ser. 3,16 (6) : 1-105, 48 text-figs.

Shommaker, C. R. 1920. The Amphipods of the Canadian Arctic Exped. 1913-18. Rep. Canadian Arctic Exped., vol. 7, pt. E: 1-30, 6 text-figs.

1930. The Amphipoda of the Cheticamp Exped. of 1917. Contrib. Canad. Biol. Fish., 5 : 221-359, 54 text-figs.

Stebbing, T. R. R. 1888. Report on the Amphipoda collected by H. M. S. Challenger during the years 1873-76. Rep. Sci. Res.' Voy. Challenger, vol. 29, text and Plates.

1906. Amphipoda. I Gammaridea. Das Tierreich, 21: 1-806, 127 text-figs.

StEPHEnsen, K. 1932. Some new amphipods from Japan. Annot. Zool. Japon. 13 (5): 487-501. 5 text-figs.

text-figs.

1944. Some Japanese amphipods. Vid. Medd. Dansk Naturh. Foren., 108: 25-88, 33 